Diklus: Jurnal Pendidikan Luar Sekolah, 2(2), September 2018 - 153

Nanang Kristanto

\title{
DESAIN KURIKULUM KURSUS DAN PELATIHAN KOMPUTER (APLIKASI PERKANTORAN) PADA SANGGAR KEGIATAN BELAJAR (SKB) UNTUK MENINGKATKAN MUTU LULUSAN DI PROVINSI DAERAH ISTIMEWA YOGYAKARTA
}

\author{
Oleh : Nanang Kristanto \\ Balai Pengembangan Pendidikan Anak Usia Dini Dan Pendidikan Masyarakat Papua / Sps UPI \\ nanang.kristanto@kemdikbud.go.id \\ Rusman \\ Kaprodi Pengembangan Kurikulum Sps UPI \\ rusman821971@gmail.com
}

\begin{abstract}
ABSTRAK
Penelitian ini merupakan studi pendahuluan atas masalah dan keresahan yang muncul pada kursus dan pelatihan komputer pada sanggar kegiatan belajar. Dengan beralih fungsinya SKB menjadi satuan pendidikan maka menjadi tantangan baru dalam dunia pendidikan Non-formal. Penelitian ini bertujuan untuk mengetahui kondisi kursus dan pelatihan di SKB serta mencari solusinya. Dalam kegiatan penelitian ini mengunakan pendekatan kualitatif dengan metode Research and Development $(R \& D)$. Prosedur pada penelitian mengacu pada perdirjen PAUD dan Dikmas . Dalam penelitian ini ditempuh tiga langkah yaitu 1).studi pendahuluan,2).pengembangan desain,3).validasi. Dari hasil studi pendahuluan didapat bahwa lulusan kursus dan pelatihan komputer (aplikasi perkantoran) mutu lulusannya rendah, hal tersebut dibuktikan dengan sedikitnya kepemilikan sertifikat kompetensi yang terakreditasi. Data menujukan hanya sebesar $1,21 \%$ dari total peserta kursus yang mengikuti ujian kompetensi/profesi. Fakta tersebut diperkuat dengan keterserapan lulusan pada dunia usaha dan dunia industri yang rendah. Data nasional menunjukkan bahwa kursus dan pelatihan komputer menempati urutan pertama dengan jumlah terbayak lulusan yang masih menunggu penempatan/mengggur. Belum terakreditasinya sanggar kegiatan belajar serta perubahan alih fungsi SKB menjadi satuan pendidiakan menjadi permasalahan selanjutnya yang mengkibatkan rendahnya mutu lulusan. untuk itu perlu dilakukan penelitian lebih lanjut tentang pengembangan desain kurikulum kursus dan pelatihan komputer (aplikasi perkantoran) untuk meningkatkan mutu lulusan pada sanggar kegiatan belajar di Provinsi Daerah Istimewa Yogyakarta, selanjutnya pengembangan desain kurikulum Penelitian ini hanya mengembangkan produk berupa desain kurikulum pelatihan secara teoritis saja, tidak sampai pada uji coba empirik.
\end{abstract}

Kata kunci : Desain, kurikulum, kursus dan pelatihan,mutu lulusan, SKB

\section{PENDAHULUAN}

Pergeseran kebutuhan pendidikan

dari kebutuhan akan pengetahuan menjadi kebutuhan akan ketrampilan, menjadi awal baru dalam dunia pendidikan. Perubahan pola pendidikan yang begitu cepat dan silih berganti serta globalisasi di segala bidang termasuk bidang pendidikan mengakibatkan hasil pendidikan yang diperoleh disekolah (pendidikan formal) menjadi tidak sesuai lagi dengan tuntutan baru kebutuhan dunia 


\section{Diklus: Jurnal Pendidikan Luar Sekolah, 2(2), September 2018 - 154 \\ Nanang Kristanto}

kerja, dunia industri, karna pada dasarnya seseorang menempuh pendidikan untuk mendapatkan pekerjaan yang layak atau membagun wirausaha. Kebutuhan masyarakat akan ketrampilan tidak didapatkan disekolah, melainkan di luar sekolah. Pendidikan luar sekolah atau yang kita kenal dengan Pedidikan Non-formal dan Infomal (PNF) mampu memberikan layanan pendidikan ketrampilan bagi semua orang tanpa mengenal batas usia dan status sosial. Pendidikan non-formal adalah jalur pendidikan di luar pendidikan formal yang dapat dilaksanakan secara terstruktur dan berjenjang. Hasil pendidikan non-formal dapat dihargai setara dengan hasil program pendidikan formal setelah melalui proses penilaian penyetaraan oleh lembaga yang ditunjuk oleh Pemerintah atau Pemerintah Daerah dengan mengacu pada standar nasional pendidikan.

Salah satu bentuk layanan PNF sesuai dengan undang undang sisdiknas adalah Pendidikan Kursus dan pelatihan. UU NO 20 Th 2003, Pasal 26 disebutkan bahwa kursus dan pelatihan diselenggarakan bagi masyarakat yang memerlukan bekal pengetahuan, keterampilan, kecakapan hidup, dan sikap untuk mengembangkan diri, mengembangkan profesi, bekerja, usaha mandiri, dan/atau melanjutkan pendidikan ke jenjang yang lebih tinggi. Dalam pelaksanaannya kursus dan pelatihan dilaksanakan oleh pemerintah melalui lembaga pemerintah dan swasta. Pada lembaga pemerintah terutama diselenggarakan oleh sanggar kegiatan belajar (SKB) dan lembaga swasta diselenggarakan oleh lembaga kursus dan pelatihan (LKP) atau satuan pendidikan nonformal yang lainnya.

Berdasarkan Surat Edaran Dirjen PAUD dan Dikmas kepada seluruh Kepala Daerah dengan surat nomor : 1086/C.C4.I/PR/2015 tertanggal 3 Juli 2015, Kementerian Pendidikan dan Kebudayaan RI meminta kepada seluruh Kepala Daerah untuk mengubah fungsi sanggar kegiatan belajar (SKB) menjadi satuan pendidikan non-formal sejenis. Yang kemudian diikuti dengan di tandatanganinya Permendikbud No 4 Tahun 2016 tentang pedoman alih ungsi sanggar kegiatan belajar menjadi satuan pendidikan non-formal oleh Menteri Pendidikan dan Kebudayaan, status SKB menjadi sama dengan LKP atau satuan pendidikan non-formal lainya, yaitu samasama menjadi satuan pendidikan non-formal. Yang membedakan antara SKB dengan satuan pendidikan non-formal lainya adalah SKB merupakan satuan pendidikan nonformal Negeri. Salah satu fungsi SKB alih fungsi menjadi satuan pendidikan adalah menjadi penyelenggaraan program percontohan pendidikan non-formal. Maka diharapkan SKB menjadi contoh bagi satuan 


\section{Diklus: Jurnal Pendidikan Luar Sekolah, 2(2), September 2018 - 155 \\ Nanang Kristanto}

pendidikan yang lain nya dalam menyelengarakan program-program pendidikan, salah satunya program kursus dan pelatihan.

Dengan adanya perubahan alih fungsi SKB sesuai Permendikbud nomor 4 Tahun 2016 menjadi satuan pendidikan nonformal sejenis memiliki tugas dan fungsi pengelolaan dan penyelenggaraan program pendidikan non-formal. Sesuai dengan pasal 1 bahwa SKB adalah unit pelaksana teknis dinas yang menangani urusan pendidikan pada kabupaten/kota yang berbentuk satuan pendidikan non-formal sejenis yang menyelenggarakan program pendidikan nonformal. Dimana Program PNF adalah layanan pendidikan yang diselenggarakan untuk memberdayakan masyarakat melalui : 1) pendidikan kecakapan hidup, 2) pendidikan anak usia dini, 3) pendidikan kepemudaan, 4) pendidikan pemberdayaan perempuan, 5) pendidikan keaksaraan, 6) pendidikan keterampilan dan pelatihan kerja, 7) pendidikan kesetaraan, 8) pendidikan lain yang ditujukan untuk mengembangkan kemampuan peserta didik. Salah satu bentuk pendidikan yang deselengarakan oleh SKB adalah kursus dan pelatihan. menjadi menarik ketika sekarang SKB beralih fungsi menjadi satuan pendidikan non-formal. rangkaian penelitian yang akan dilakukan oleh penulis. Rangkaian penelitian yang dimaksud penulis adalah metode yang digunakan dalam penelitian ini. Dalam penelitian ini pendekatan yang digunakan adalah kualitatif, dengan motode penelitian dan pengembangan (Research and Development). Metode penelitian dan pengembangan (Research and Development) didasarkan pada konsep yang dikemukakan oleh Van den Akker (2006: 35). Namun pada pelaksanaanya penelitian metode R\&D mengikuti konsep yang dielaskan oleh Borg \& Gall, sedangkan prosedur penelitian mengacu pada Peraturan Direktur Jenderal Pendidikan Anak Usia Dini Dan Pendidikan Masyarakat Kementerian Pendidikan Dan Kebudayaan no 2 tahun 2016 tentang petunjuk teknis pengembangan model pendidikan anak usia dini dan pendidikan masyarakat.

\section{METODE}

Artikel ini adalah bagian dari 


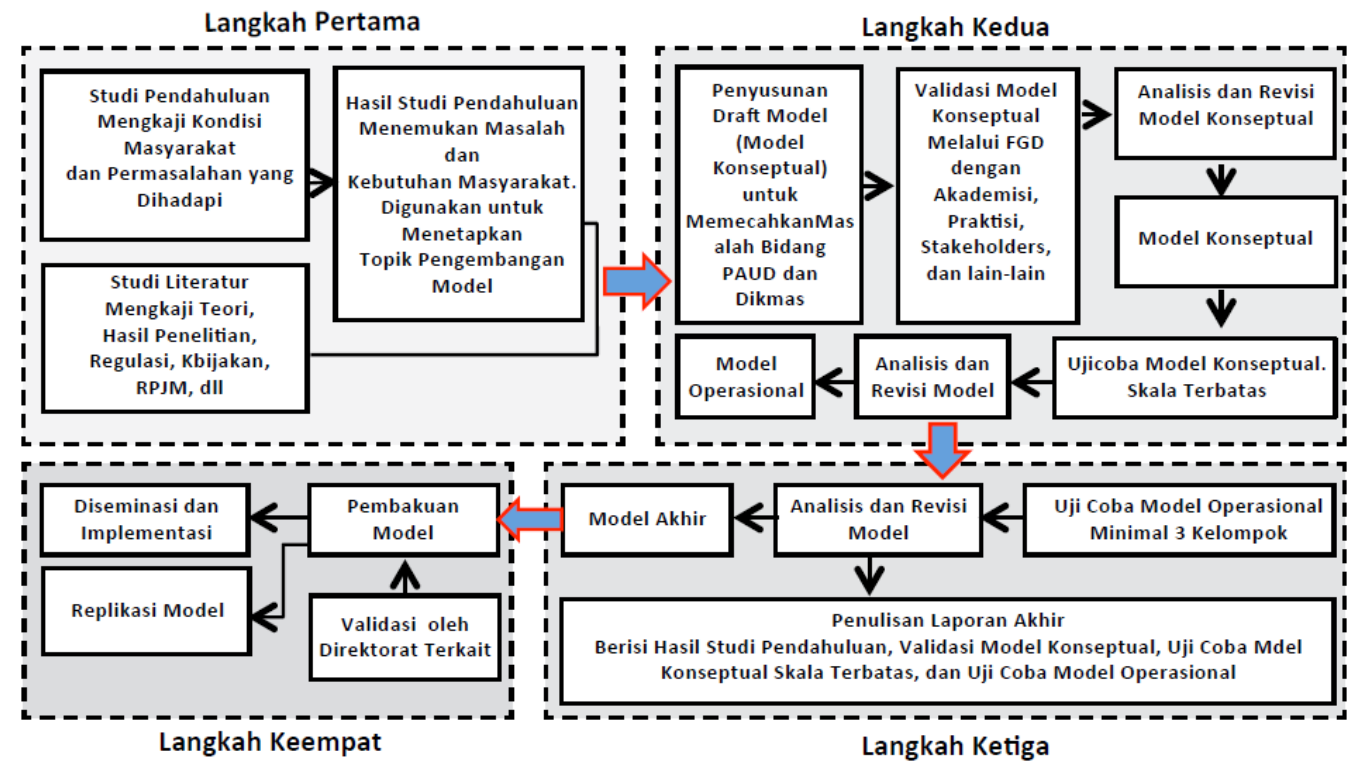

Terdapat empat langkah dalam prosedur penelitian dan pengembangan (Research and Development). Namun dalam artikel ini merupakan bagian dari analisi awal. Yang dalam bagan tersebut diatas merupakan langkah pertama. Langkah pertama yang dimaksud adalah studi pendahuluan untuk mengkaji kondisi dan permasalahn yang sebenarnya dilapangan terkait dengan kursus komputer aplikasi perkantoran. Sehingga hasil akhir akan dikembangkan roduk yang tepat berdasarkan dari hasil studi pendahuluan ini. Dalam proses nya studi pendahuluan ini mengunakan metode FGD serta studi kepustakaan.

\section{HASIL DAN PEMBAHASAN}

Dengan adanya perubahan alih fungsi SKB sesuai Permendikbud nomor 4 Tahun 2016 menjadi satuan pendidikan non-formal sejenis memiliki tugas dan fungsi pengelolaan dan penyelenggaraan program pendidikan non-formal. Sesuai dengan pasal 1 bahwa SKB adalah unit pelaksana teknis dinas yang menangani urusan pendidikan pada kabupaten/kota yang berbentuk satuan pendidikan non-formal sejenis yang menyelenggarakan program pendidikan nonformal. Dimana Program PNF adalah layanan pendidikan yang diselenggarakan untuk memberdayakan masyarakat melalui

: 1) pendidikan kecakapan hidup, 2) pendidikan anak usia dini, 3) pendidikan kepemudaan, 4) pendidikan pemberdayaan perempuan, 5) pendidikan keaksaraan, 6) pendidikan keterampilan dan pelatihan kerja, 7) pendidikan kesetaraan, 8) pendidikan lain yang ditujukan untuk mengembangkan kemampuan peserta didik.

Selama ini kursus dan pelatihan banyak diselengarakan oleh LKP sedangkan 


\section{Diklus: Jurnal Pendidikan Luar Sekolah, 2(2), September 2018 - 157 \\ Nanang Kristanto}

SKB sebelum alih fungsi menjadi satuan pendidikan non-fomal lebih banyak menyelenggarakan program dari pemerintah sesuai dengan bentuk bantuan yang didapat, walaupun dalam perencanaannya juga berdasarkan kebutuhan dilapangan. Perkembangan kursus dan pelatihan berkaitan erat dengan perkembangan LKP, Perkembangan keberadaan LKP di Indonesia sangat luar biasa, berdasarkan data dari Direktorat Pembinanaan Kursus dan Pelatihan bahwa data LKP tahun 2007 sebanyak 9.642 lembaga, sedangkan data tahun 2010 meningkat tajam menjadi 14.315, tahun 2015 menjadi 17.776 dan tahu ini menjadi 19.794. artinya dalam kurun waktu hanya 5 tahun meningkat sebesar $56,5 \%$, dengan beraneka ragam keterampilan, saat ini ada 224 jenis keterampilan dan dari 224 tersebut 76 jenis keterampilan sudah dibakukan.

Fenomena peningkatanya jumlah lembaga kursus ini sayangnya belum diiringi dengan peningkatan mutu kursus dan pelatihan yang ditandai dengan penyediaan sarana prasarana yang memadai, tenaga pendidik dan kependidikan yang kompeten, kurikulum yang sesuai dengan perkembangangan zaman serta sesuai dengan standar minimal yang telah ditentukan oleh pemerintah. (Dirjen PAUD dan Dikmas: Saatnya Lembaga Kursus Berbenah, 2015) Pada Tahun
2015 Sebanyak 17.776 Lembaga Kursus dan Pelatihan (LKP) yang ada di Indonesia baru berjumlah delapan persen saja yang telah mendapatkan akreditas dari pemeritah. Jika dihitung jumlahnya sekitar 1.200-an LKP yang mendapatkan akreditasi. 17.776 LKP tersebut terdiri dari 24 ribu macam kursus dari 97 jenis kursus.

Fungsi LKP harusnya mampu memberikan pendampingan kepada peserta didik agar memiliki kompetensi, bersertifikat dan masuk dunia kerja atau berwirausaha. Sayangnya kualitas layanan yang diberikan oleh LKP tidak sesuai dengan apa yang diharapkan, Berdasarkan data dari Direktorat Pembinaan Kursus dan Pelatihan yang ditulis Ginting dalam Info Kursus, hasil penilaian kinerja tahun 2009 dan 2010 berkinerja A (1,7\%), B $(20,3 \%), C(35,7 \%)$ dan D (42,3\%). Dari data tersebut di atas berarti bahwa keberadaan kursus yang kurang memenuhi standar atau berkinerja D masih lebih banyak, sementara berkinerja sangat baik atau A ternyata masih sangat sedikit. Pada Tahun 2016 hasil penilaian kinerja dari 749 lembaga yang dinilai kinerjanya, yang berkinerja A $(2,1 \%)$, B $(22,6 \%)$, C $(34,8 \%)$ dan D $(40,5 \%)$. Penilaian kinerja bagi LKP merupakan salah satu upaya pemerintah untuk memetakan serta dapat fokus membina secara berkesinambungan pada LKP sesuai 
Diklus: Jurnal Pendidikan Luar Sekolah, 2(2), September 2018 - 158

\section{Nanang Kristanto}

dengan kebutuhan berdasarkan penilaian

kinerja yang

diperolehnya, sehingga akan berdampak

pada kualitas layanan kursus dan

pelatihan yang diselenggarakan.
Mutu lulusan juga dapat dilihat dari jumlah peserta didik yang lulus. Berdasarkan data informasi eksekutif dalam www.infokursus.net berikut merupakan rekapitulasi status lulusan LKP

Tabel 1. Rekapitulasi Status Kelulusan program Kursus di LKP

\begin{tabular}{|l|c|c|}
\hline \multicolumn{1}{|c|}{ Status } & \multicolumn{2}{c|}{ Jumlah } \\
\hline Proses Pendidikan \& Pelatihan & 20.182 & $13.11 \%$ \\
\hline Bekerja & 70.338 & $45.68 \%$ \\
\hline Usaha Mandiri & 14.283 & $9.28 \%$ \\
\hline Menunggu Penempatan / Menganggur & 49.168 & $31.93 \%$ \\
\hline Total & 153.971 & $100 \%$ \\
\hline
\end{tabular}

Sumber: www.infokursus.net (diakses 28/03/17) 


\section{Diklus: Jurnal Pendidikan Luar Sekolah, 2(2), September 2018 - 159 \\ Nanang Kristanto}

Kondisi status lulusan tersebut dapat diartikan bahwa masih banyak lulusan kursus dan pelatihan yang menunnggu penempatan/menganggur. Banyaknya lulusan kursus yang menunggu penempatan / menganggur mengidikasikan bahwa lulusan kursus belum memenuhi standart kompetensi. Berkompeten atau tidak nya lulusan kursus dan pelatihan dibuktikan dengan lulus tidaknya peserta kursus mengikuti ujian. Secara legal formal perserta kursus akan mendapatkan sertifikat atau ijazah baik itu di akui oleh Lokal, Nasional dan Internasional. Jika disimpulkan dari data lulusan, terutama terkait dengan kompetensi lulusan kursus dan pelatihan, dapat dinyatakan bahwa kompetensi lulusan kursus dan pelatihan itu rendah.

Rendah nya kompetensi lulusan kursus dan pelatihan juga dapat dilihat dari berapa banyak peserta didik kursus dan pelatihan yang mengikuti ujian kompetensi . Data yang diperoleh dari Infokursus pada tahun 2007 menyatakan bahwa Penyelenggaraan ujian kursus dapat dibedakan menjadi (4) empat macam yaitu ujian lokal/lembaga $(79,50 \%)$, ujian nasional (17,50\%), ujian internasional $(1,79 \%)$ dan ujian kompetensi atau profesi $(1,21 \%)$. Dari keempat jenis ujian tersebut berhasil meluluskan sebanyak 798.845 atau $(90,14 \%)$, ujian nasional 78.942 atau $(8,91 \%)$ dan ujian internasional sebanyak 8.398 atau $(0,95 \%)$.

Berdasarkan data tersebut terlihat bahwa proses evaluasi dalam program kursus dan pelatihan dilalui melalui tahap ujian di tingkat lokal, nasional maupun internasional. Untuk mengejar standar mutu, uji kompetensi bagi peserta didik sangat penting, sebagai tanda penghargaan atas kemampuan yang dimilikinya. Seperti dijelaskan di dalam UU No 20, Tahun 2003, pasal 61 ayat 3: Sertifikasi kompetensi diberikan oleh penyelenggara pendidikan dan lembaga pelatihan kepada peserta didik dan warga masyarakat sebagai pengakuan terhadap kompetensi untuk melakukan pekerjaan tertentu setelah lulus uji kompetensi yang diselenggarakan oleh satuan pendidikan yang terakreditasi atau lembaga sertifikasi.

Sayangnya masih sedikit peserta kursus yang mengikuti uji kompetensi. Uji kompetensi adalah proses pengujian dan penilaian yang dilakukan oleh penguji untuk mengukur tingkat pencapaian kompetensi hasil belajar peserta didik pada suatu jenis dan tingkat pendidikan tertentu. Uji kompetensi diselenggarakan oleh lembaga sertifikasi kompetensi (LSK) sejak tahun 2009. LSK adalah lembaga mandiri yang dibentuk oleh organisasi atau asosiasi profesi yang diakui Pemerintah. Tempat uji 
Diklus: Jurnal Pendidikan Luar Sekolah, 2(2), September 2018 - 160

\section{Nanang Kristanto}

kompetensi (TUK) adalah lembaga kursus

dan/atau satuan pendidikan non-formal lain

atau lembaga yang telah dinilai,

diverifikasi, dan ditetapkan oleh lembaga

sertifikasi kompetensi (LSK) untuk

menyelenggakan uji kompetensi. Untuk

dapat mengikuti uji kompetensi satuan

pendidikan mendaftarkan peserta kursus

yang sudah menyelesaikan pendidikan \&

pelatihanya kepada LSK. Alur tersebut

tergambar seperti berikut : 


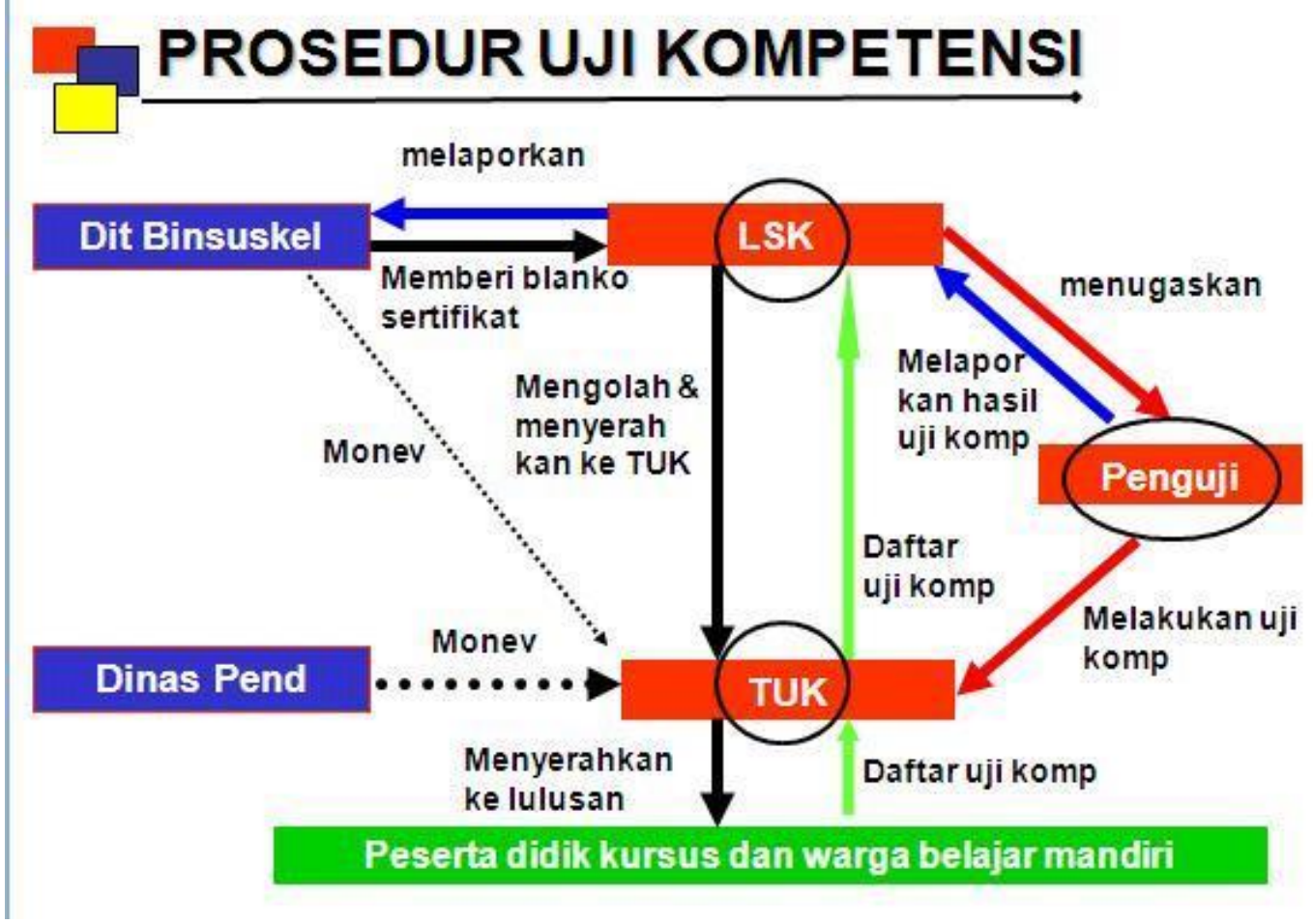

Bagan 1. Prosedur Uji Kompetensi

Sumber: www.infokursus.net (diakses 28/03/17)

Terbatasnya TUK menjadi kendala bagi peserta didik untuk dapat mengikuti uji komptensi. Berdasarkan data dari sistim informasi ekslusif Direktorat Binsuslat hanya terdapat 1146 TUK yang tersebar di seluruh indonesia. Sedikitnya lulusan kursus dan pelatihan yang mempunyai sertifikat kompetensi membuat lulusan tidak mampu bersaing untuk mendapatkan pekerjaan. Akhirnya lulusan kursus dan pelatihan hanya mampu menyumbang angka pengangguran di indonesia. (BPS: Pengangguran Terbuka di Indonesia Capai
7,02 Juta Orang,2016) - Kepala Badan Pusat Statistik (BPS) Suryamin mengatakan tingkat pengangguran terbuka pada Februari 2016 mencapai 7,02 juta orang atau 5,5 persen. SKB Sebagai salah satu satuan pendidikan non- formal yang salah satu fungsinya menyiapkan tenaga kerja, dituntut mampu menghasilkan lulusan sebagaimana yang diharapkan oleh dunia kerja. Dunia kerja membutuhkan tenaga kerja yang memiliki kompetensi sesuai dengan bidang pekerjaannya, memiliki daya adaptasi dan daya saing yang tinggi. Atas 


\section{Diklus: Jurnal Pendidikan Luar Sekolah, 2(2), September 2018 - 162 \\ Nanang Kristanto}

dasar itu, SKB harus menyuguhkan layanan pembelajaran yang berkualitas. selama ini SKB maupun satuan pendidikan nonformal lainya dalam menyelengarakan kegiatan kursus dan pelatihan mengunakan kurikulum yang telah disusun oleh direktorat Pembinaan Kursus dan pelatihan. Kurikulum yang selama ini disusun oleh direktorat adalah kurikulum berbasis kompetensi (KBK). Seperti yang tertuang dalam UU sisdiknas Pasal 6 ayat 3 "satuan pendidikan non-formal dalam bentuk kursus dan lembaga pelatihan menggunakan kurikulum berbasis kompetensi yang memuat kecakapan hidup dan ketrampilan". Pada dasarnya kurikulum yang ada disetiap jenis kursus bersifat nasional. Namun sampai tahun 2017 baru 76 jenis kursus dengan berbagai jenjang baru disyahkan dan dibuat oleh pemerintah. Hal tersebut membuat satuan pendidikan non-formal mengalami kesulitan dalam menyelengarakan kursus yang sesuai dengan kebutuhan dunia usaha dan dunia industri apabila belum ada kurikulum yang dibuat atau sesuai dengan yang dibutuhkan. Dari peryantaan tersebut dapat dicari solusi tentang bagaimana mengembangakan LKP yang bermutu sesuai dengan kebutuhan dunia usaha dan dunia industri, khususnya melalui kurikulum.
Kurikulum mempuyai kedudukan yang sentral dalam seluruh proses pendidikan, begitu juga dalam proses kursus dan pelatihan pada LKP. Kurikulum megarahkan segala bentuk aktivitas pendidikan demi tercapianya tujuan pendidikan. Menurut Mauritz jhonson (1967, hal.130) kurikulum "prescribe (or at last anticipates) the result of instruction. Kurikulum juga merupakan suatu rencana pendidikan memberikan pedoman dan pegangan tentang jenis lingkup dan urutan isi serta proses pendidikan. Kurikulum yang sudah disyahkan oleh pemerintah sayangnya tidak semuanya mampu mengimbangi perkembagan perubahan kebutuhan, hal tersebut yang membuat lulusan kurus dan pelatihan tidak mampu bersaing.

Mengingat jenis kursus sangat bervariasi, maka dalam penelitian ini akan mengambil jenis kursus berdasarkan banyaknya lulusan yang masih menunggun penempatan. Berikut data 10 jenis kursus bersadarkan kelulusannya. 
Diklus: Jurnal Pendidikan Luar Sekolah, 2(2), September 2018 - 163

\section{Nanang Kristanto}

Tabel 2. 10 Jenis Kursus Berdasarkan Kelulusannya

\begin{tabular}{|c|c|c|c|c|c|c|c|c|c|c|}
\hline \multirow[t]{2}{*}{ No } & \multirow{2}{*}{$\begin{array}{c}\text { Jenis } \\
\text { Ketrampilan }\end{array}$} & \multicolumn{2}{|c|}{ Proses Diklat } & \multicolumn{2}{|c|}{ Bekerja } & \multicolumn{2}{|c|}{$\begin{array}{c}\text { Berwirausah } \\
\mathbf{a}\end{array}$} & \multicolumn{2}{|c|}{$\begin{array}{l}\text { Menunggu } \\
\text { Penempatan }\end{array}$} & \multirow{2}{*}{ Jumlah } \\
\hline & & $\mathrm{L}$ & $\mathrm{P}$ & $\mathrm{L}$ & $\mathrm{P}$ & $\mathrm{L}$ & $\mathrm{P}$ & $\mathrm{L}$ & $\mathrm{P}$ & \\
\hline 1 & Komputer & 4183 & 4919 & 12472 & 13803 & 1952 & 1524 & 13351 & 18207 & \multirow{2}{*}{$\begin{array}{c}70411 \\
8678 \\
\end{array}$} \\
\hline 2 & Mengemudi & 282 & 196 & 1666 & 827 & 228 & 121 & 3121 & 2237 & \\
\hline 3 & $\begin{array}{l}\text { Bahasa } \\
\text { Inggris }\end{array}$ & 1216 & 1574 & 1143 & 1185 & 131 & 92 & 2269 & 3000 & 10610 \\
\hline 4 & Menjahit & 36 & 675 & 858 & 7002 & 218 & 4367 & 121 & 1603 & 14880 \\
\hline 5 & Otomotif & 367 & 2 & 2151 & 11 & 801 & 5 & 1333 & 36 & 4706 \\
\hline 6 & Akuntansi & 146 & 531 & 401 & 1488 & 6 & 34 & 171 & 520 & 3297 \\
\hline 7 & Perhotelan & 853 & 626 & 1539 & 1051 & 32 & 11 & 187 & 112 & 4411 \\
\hline 8 & Elektronika & 32 & 3 & 253 & 33 & 436 & 52 & 201 & 23 & 1033 \\
\hline 9 & $\begin{array}{l}\text { Tata } \\
\text { Kecantikan } \\
\text { Rambut } \\
\end{array}$ & 6 & 130 & 33 & 753 & 44 & 999 & 28 & 189 & 2182 \\
\hline 10 & Spa & 13 & 284 & 135 & 1274 & 7 & 216 & 16 & 292 & 2237 \\
\hline
\end{tabular}

(data diolah dari infokursus.net) 


\section{Diklus: Jurnal Pendidikan Luar Sekolah, 2(2), September 2018 - 164 \\ Nanang Kristanto}

Berdasarkan data diatas menunjukan bahwa kursus dan pelatihan komputer menjadi jenis ketrampilan dengan jumlah peserta didik terbanyak yang sedang menunggu penempatan. Sehingga jenis kursus yang akan menjadi fokus penelitian ini adalah kursus dan pelatihan komputer.

Banyaknya lulusan kursus dan pelatihan komputer yang menunggu penempatan menunjukan lulusan kurus dan pelatihan komputer belum memenuhi standar kompetensi yang dibutuhkan, serta banyaknya lulusan yang tidak mengikuti uji kompetensi melalui TUK, sehingga lulusan tidak mempunyai sertifikat kompetensi yang diakui secara nasional menyebabkan lulusan kursus tidak mampu bersaing untuk mendapatkan pekerjaan yang sesuai dengan kompetensinya. Selama ini lulusan kursus banyak berasal dari LKP, yang pada kenyataanya mereka lulus mengikuti ujian pada tingkat lokal, yaitu ujian yang diselengarakan oleh lembaga, namun mereka tidak mengikuti uji kompetensi di tempat TUK. Dalam hal ini LKP sudah gagal mengantarkan peserta didik lulus berkompeten serta mempunyai sertifikat kompetensi. Dengan adanya SKB menjadi satuan pendidikan non-formal yang baru, Maka peneliti ingin membuat desain kurikulum yang mampu meningkatkan mutu lulusan kursus dan pelatihan, sehingga mereka berkompeten serta mempunyai sertifikat kompetensi dari lembaga sertifikasi kompetensi, agar menjadi contoh lembaga pendidikan non-formal lainnya.

\section{PENUTUP}

Berdasarkan hasil studi pendahuluan ini maka dirumuskanlah solusi untuk mengatasi permasalahn tingginya angka pengangguran lulusan kursus komputer (aplikasi perkantoran), dari hasil studi pendahuluan didapatkan masukan masukan yang selanjutnya menjadi bahan kajian pada langkah ke dua dalam penelitian dan pengembangan (R\&D). dari hasil kajian diatas maka perlu dikembangkan desain kurikulum kursus dan pelatihan komputer (aplikasi perkantoran) pada sanggar kegiatan belajar (skb) untuk meningkatkan mutu lulusan di provinsi daerah istimewa Yogyakarta.

\section{DAFTAR PUSTAKA}

Aan Komariah dan Djam'an Satori. (2012).

Metodologi Penelitian Kualitatif. Bandung:

Alfabeta. Abdulhak, I (2000). Metodologi

Pembelajaran Orang Dewasa. Bandung:

Indira Alma Buchori.

Akker, J Van Den. (2006). Chapter 1: Principles and Methods of Development Research dalam

Educational Design Research, Arizona: Rotledge. 
Andrew E. Sikula (1981). Pelatihan dan pengembangan tenaga kerja. Jakarta : bina pustaka. Borg Walter R., Meredith Damien

Gall. 1983. Educational Research an Introduction. New York: Longman Inc.

Borg, W.R.\&Gall, M.D (1989). Educational Research: An Introduction (5

London: Longman, Inc.Ed). New York \&BPS: Pengangguran Terbuka di Indonesia Capai 7,02 Juta Orang.(2016, Mei). Kompas Rabu, 4 Mei 2016 18:49 WIB, from : https://nasional.tempo.co

Deming, W. Edwards. 1982. Guide to Quality Control. Cambirdge: Massachussetts Institute Of Technology.

Departemen Pendidikan Nasional. (2002). Pedoman Penyelenggaraan Program Kecakapan Hidup (Life Skill) Pendidikan Non Formal. Jakarta: Dirjen Diklusepa.

Direktorat Kursus dan kelembagaan(2010). From : www.infokursus.net

Dirjen PAUD dan DIKMAS.(2015).Saatnya Lembaga Kursus Berbenah.(2015, Mei).

Harian sore

Sinar Harapan, 22 Mei 2015, from: http://scholae.co.

Edward Sallis, 2006. Total Quality

Management in Education. Jogjakarta:IRCiSoD

Edward Sallis. 2008. Total Quality Management In Education (alih Bahasa Ahmad Ali Riyadi). Jogjakarta : IRCiSoD.

Eisner, E. W., Vallance, E. (1974). Five conceptions of curriculum: Their roots and implications for curriculum planning. In E. W. E. E. Vallance (Ed.), Conflicting Conceptions of Curriculum (pp. 118). Berkley, PA: McCutchan Publishing.

Hamalik, O. (2007). Dasar-dasar pengembangan kurikulum. Bandung: PT Remaja Rosdakarya Offset.

Hamalik, Oemar. (1993). Dasar-Dasar Pengembangan Kurikulum. Bandung: PT. Remaja Rosdakarya.

Hugh Barr.(2000). Designing and Developing a Constructivist National Social Studies Curriculum: An Example from New Zealand. Children's Social And Economics Education Vol. 4, No. 1.

Juran, J.M. (1992). Juran Quality By

Design, New York: Free Press

Kementerian Pendidikan dan Kebudayaan.(2013). Analisis Mutu Kursus Disusun oleh: Bidang Pendayagunaan dan Pelayanan Data dan Statistik Pendidikan. Jakarta: Pusat Data dan Statistik Pendidikan, Kemdikbud, 2013

Keputusan Menteri Pendidikan dan Kebudayaan Republik Indonesia Nomor : 0206/ O/ 1978 tanggal 23 Juni 1978 tentang Susunan Organisasi dan Tata Kerja Sanggar Kegiatan Belajar.

McNeil, J.D. (2006). Contemporary

Curriculum In Thought and Action - Sixth Edition. New Jersey: Willey Jossey-Bass Education.

Munthe, B. ( 2009). Desain Pembelajaran. Yogyakarta: Pustaka Insan Madani 
Ornstein, Allan C. \& Francis P. Hunkins. (2009) Curriculum: Foundations, principles, and Issues.

Edisi ke-5. New Jersey: Pearson Education, Inc.

Peraturan Dirjen PAUD dan Dimas No 2 Tahun 2016 Tentang Petunjuk Teknis Pengembangan

Model Pendidikan Anak Usia Dini

Dan Pendidikan Masyarakat.

Peraturan Dirjen PAUD dan Dimas Nomor 1453 tahun 2016 Tentang Petunjuk Teknis Satuan

Pendidikan Nonformal Sanggar Kegiatan Belajar.

Peraturan Menteri Pendidikan Nasional Nomor 70 Tahun 2008 tentang Uji Kompetensi Bagi Peserta Didik Kursus dan Pelatihan Dari Satuan Pendidikan Nonformal atau Warga Masyarakat yang Belajar Mandiri.

Peraturan Pemerintah No. 19 tahun 2005 tentang Standar Nasional Pendidikan.

Peraturan Pemerintah Nomor 13 Tahun 2015, Perubahan Kedua Atas Peraturan Pemerintah Nomor 19 Tahun 2005 Tentang Standar Nasional Pendidikan.

Permendikbud No 131 tahun 2014 tentang standar kompetensi lulusan kursus dan pelatihan. Permendikbud No 4 Tahun 2016 tentang Pedoman Alih Fungsi Sanggar Kegiatan Belajar menjadi Satuan Pendidikan Nonformal.

Ravi, V. (2016). Curriculum Development. Slapur: Laxmi Book Publication

Riduwan dan Kuncoro. 2007. Cara Menggunakan dan Memaknai Analisis Jalur (Path Analysis). Bandung:
Alfabeta.

Sanjaya, Wina. Kurikulum Pembelajaran, Teori dan Praktek Pengembangan Kurikulum Tingkat Satuan Pendidikan (KTSP). Jakarta: Kencana Prenada Media Group, cet, 3, 2008.

Saylor J. Glan; Alexander, William M; dan Lewis, Artur J. (1981). Curriculum Planing for batter

Teaching and Learning, New York, Rinehartand Wiston.

Schuler. Randall S. (1987). Personel and Human Resource Management, Third edition, New

York: West Publishing Company.

Schuller, Randall. (1997). Manajemen Sumber Daya Manusia Menghadapi Abad ke 21. Jakarta: Erlangga.

Soetomo, S. et al. (1988). Pengembangan Kursus. Kerjasama Universitas Terbuka dengan Direktorat Jenderal Pendidikan Luar Sekolah, Pemuda dan Olah Raga.

Sowiyah. 2010. Pengembangan Kompetensi Guru SD. Lampung: Lemlit UNILA.

Suhardan, D., Riduwan, \& Enas. 2012. Ekonomi dan Pembiayaan Pendidikan. Bandung: Alfabeta.

Sukmadinata, Nana, 2010, Pengembangan kurikulum teori dan peraktek. Bandung: Kusuma Karya

Threfall, Mike. Planning Across the Curriculum. dalam Kate Ashcroft and David Palacio.Implementing the Primary Curriculum, A Teachers Guide. Washington DC: The Falmer Press, 1997.

Undang-Undang No 22 Tahun 1999. 
Diklus: Jurnal Pendidikan Luar Sekolah, 2(2), September 2018 - 167

\section{Nanang Kristanto}

Tentang Pemeritah Daerah

Undang-undang Republik Indonesia Nomor

20 tahun 2003 tentang Sistem Pendidikan

Nasional (Sisdiknas). Jakarta: Sinar Grafika.

Wills, Mike. (1993), Managing the

Training Process: Putting the

Basies Into Practice, London: Mc.

Graw Hill Book company Europe.

Zais, Robert S. (1976). Curriculum:

Principles and Foundations. New York:

Harper \& Row. Publisher. 